\title{
MAZHAB NEGARA: ALTERNATIF SOLUSI TERHADAP PERBEDAAN PENENTUAN AWAL BULAN QAMARIYAH DI INDONESIA
}

\author{
Wanti Marpaung \\ (Dosen Fakultas Syariah dan Hukum UIN Sumatera Utara Medan)
}

\begin{abstract}
The article discusses that "mazhab negara" is a new ideas and solution on moslim's problem. There are different among moslem Indonesia on starting past Ramadhan, syawal and the others. "Mazhab Negara" at least will become to clear long time problem among Moslem Indonesia.

Keywords: penetapan awal bulan, mazhab negara, rukyat, hisab.

Abstrak: Artikel ini membahas bahwa "mazhab negara" adalah ide dan solusi baru tentang masalah muslim. Ada perbedaan di antara umat Islam Indonesia dalam memulai melewati Ramadhan, syawal dan yang lainnya. "Mazhab Negara" setidaknya akan menjadi masalah lama di kalangan Muslim Indonesia.

Kata Kunci: penetapan awal bulan, mazhab negara, rukyat, hisab
\end{abstract}

\section{PENDAHULUAN}

Pelaksanaan ibadah dalam Islam tidak dapat dilepaskan dari persoalan penanggalan dan waktu. Ibadah apa pun akan selalu terkait erat dengan waktu. Salat lima waktu yang dilaksanakan umat Islam sehari semalan keseluruhannya punya waktu untuk memulai dan batas akhirnya. Selain itu, penanggalan juga menjadi suatu yang niscaya dalam peribadatan umat Islam, penentuan Ramadhan, bulan Syawal dan sebagainya menjadi bahagian yang urgen.

Persoalan penetapan awal bulan atau penanggalan dalam Islam merupakan suatu hal yang serius. Keseriusan itu dapat dilihat dari datadata dalam Alquran dan Hadis baik qawli maupun fi'li. Tidak hanya berhenti pada sumber ternyata para ulama dalam semua kitab fikih akan membahas persoalan kajian penetapan awal bulan terkait dengan Ramadahan, syawal dan sebagainya. Sehingga menjadi penting untuk ditelaah dan dteliti secara kontinuitas sebagai sebuah kebutuhan umat.

Namun demikian, dalam konteks Indonesia penetapan awal bulan menjadi persoalan yang diperdebatkan. Hal ini ditengarai dengan teori dan metode yang digunakan ormas Islam Nahdahtul Ulama (NU), Muhammadiyah, Alwashliyah dan sebagainya. Sehingga muncul kecenderungan dan animo masyarakat bahwa akan selalu saja terjadi perbedaan dalam menentukan awal bulan.

Dalam konteks ini, mazhab negara sebagai salah satu solusi yang seharusnya menjadi strategi penyelesaian persoalan penetapan awal bulan di tengah umat Islam Indonesia menjadi suatu keniscayaan. Setidaknya, mazhab negara dapat menyelesaikan perbedaan yang berkepanjangan. Tulisan ini memberikan tawaran dan solusi terhadap penetapan awal bulan perspektif mazhab negara yang 
seharusnya negara dalam hal ini dapat mengambil perannya atau menegaskan perannya.

\section{DASAR PENENTUAN AWAL BULAN QAMARIYAH}

Dalam Alquran ditemukan ayatayat yang bersintuhan dengan persoalan waktu dan penanggalan. Alquran dalam konteks ini cukup beragam mengaitkannya dengan kasus, ibadah dan sebagainya, misalnya waktu shalat, pelaksanaan haji, Ramadhan, Dzulhijjah. Di antara ayat yang berkenaan demikian adalah ayat tentang pelaksanaan ibadah haji:

$$
\text { يسألونك عن الأهلة قل هي مواقت للناس والحج14 }
$$

Artinya: Mereka bertanya kepadamu tentang bulan sabit (hilal). Katakanlah: Bulan sabit itu adalah tanda-tanda waktu bagi manusia dan (ibadah) haji (Q.S. Albaqarah: 189).

$$
\text { الشمس والقمر بحسبان. }
$$

Artinya: Matahari dan bulan beredar menurut perhitungan. ${ }^{15}$

Pada dua ayat di atas, menjelaskan persoalan waktu yang terkait dengan pelaksanaan ibadah haji. Pada ayat pertama bicara mengenai hilal yang merupakan tandatanda bagi manusia dan ibadah haji. Pada hakikatnya hilal adalah tanda tidak hanya untuk ibadah haji tetapi juga ibadah-ibadah yang lain. Sementara ayat kedua menjelaskan mengenai rotasi dan titik ear matahari dan bulan yang berada pada porosnya masing-masing yang terkait erat

14 Departemen Agama, Alquran Dan Terjemahnya (Semarang: Toha Putra, 1989), hal. 234.

15 Ibid., hal. 531. dengan waktu manusia.

Sementara itu, dalam perspektif Hadis tidak sedikit juga yang membicarakan persoalan penanggalan dalam Islam. Setidaknya, di antara Hadis yang menjelaskan penanggalan tersebut sebagai berikut:

$$
\begin{aligned}
& \text { صو موا لرؤ يته و ا فطروا لرؤ يته فا ن غبي }
\end{aligned}
$$

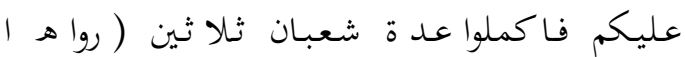

$$
\begin{aligned}
& \text { لبحا رى }
\end{aligned}
$$

Artinya: Berpuasalah kamu karena melihat hilal dan berbukalah karena melihatnya pula. Jika hilal terlindung atasmu, maka sempurnakanlah bilangan sya'ban 30 hari.

$$
\begin{aligned}
& \text { إنا أمة أمية لا نكتب ولا نحسب الشهر هكذا وهكذا }
\end{aligned}
$$

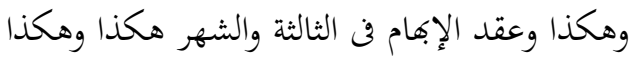

$$
\begin{aligned}
& \text { وهكذا يعنى تمام ثلاثين } 17
\end{aligned}
$$

Artinya: Kita adalah umat yang ummi, Satu bulan itu sekian, sekian, dan sekian. Beliau menekuk ibujarinya pada (perkataan sekian) yang ketiga kalinya. Dan satu bulan itu sekian, sekian, dan sekian, yakni genap 30 hari.

$$
\begin{aligned}
& \text { الشهر يكون تسعة وعشرين ويكون ثلاثين فإذا رأيتموه } \\
& \text { فصوموا وإذا رأيتموه فأفطروا فإن غم عليكم فأكملوا } \\
& \text { العدة فصنو }
\end{aligned}
$$

Artinya: Satu bulan itu ada yang duapuluh sembilan hari, dan ada pula yang tigapuluh hari. Maka apabila kamu melihat hilal maka berpuasalah dan apabila kamu melihatnya maka

16 Bukhari, Shahih Bukhari, Juz III (Beirut: Dar al-Kutub al-Ilmiyah, t.th.), hal. 478-479.

17 Muslim, Shahih Muslim, Juz I (Bairut: Darul Fikr, tth), hal. 437.

18 An-Nasa'i, Sunan an-Nasäi, Juz I (Mesir: Musthafa Babil Halabi, 1979), hal. 301.

$122 \begin{aligned} & \text { Mazhab Negara: Alternatif Solusi Terhadap Perbedaan Penentuan Awal Bulan } \\ & \text { Qamariyah Di Indonesia }\end{aligned}$ 
berbukalah. Jika penglihatanmu tertutup (oleh awan) maka sempurnakanlah bilangan itu.

Dari ketiga Hadis di atas dapat dipahami bahwa ada dua teknik cara Rasulullah dalam penanggalan atau penentuan awal bulan qamariyah. Pertama, melalui rukyat pada tanggal 29 Sya'ban, apabila hilla terlihat pada tanggal tersebut maka keesokan harinya berpuasa. Demikian juga halnya dengan penetapan 1 Syawal dengan merukyat hilal pada 29 Ramadhan jika terlihat maka keesokan harinya berbuka atau 1 Syawal. Kedua, melalui cara istikmal atau penyempurnaan bilangan bulan baik Sya'ban maupun Ramadhan jalan ini ditempuh apabila dalam penentuan 1 Ramadhan dan 1 Syawal tidak terlihat hilal pada 29 Sya'ban maupun Ramadhan. Maka dilakukan penyempurnaan bilangan bulan samapi 30 hari karena bilangan bulan sempurna sampai bilangan 30 .

Dalam kaitan ini al-Qaradlawi menegaskan bahwa Rasulullah telah melakukan pesnsyariatan terhadap umatnya pada masa itu secara alami untuk melakukan hisab kendati pun mereka ummi tidak pandai baca dan tulis. Praktik yang telah dicontohkan Rasul pada masanya tidak dapat dilepaskan dari kondisi umat yang masih sederhana dalam hitungan. Hal ini merupakan rahmat karena Allah yang tidak akan membebani mereka untuk mempraktikkan ilmu hisab yang tidak mereka kuasai. Jika seandainya Allah membebankan mereka kewajiban semacam itu, niscaya mereka akan bergantung pada umat agama lain yang relatif lebih menguasai ilmu itu. ${ }^{19}$

19 Yusuf al-Qaradlawi, Fiqh ash-Shiyam (Kairo: Dar Ash-Shahwah, 1991), hal.23.
Selanjutnya, jika seandainya mereka dibebani kewajiban menggunakan hisab berarti telah terjadi pembebanan sesuatu yang di luar kemampuan umat pada 'masa itu. Hal ini tidak dapat diterima, karena tidak sejalan dengan ruh Alquran. Praktik penentuan awal Ramadhan dan Syawal berdasarkan rukyat atau istikmal berlaku sejak zaman Nabi Muhammad Saw dan berlangsung terus sampai munculnya perkembangan ilmu hisab di kalangan muslimin mulai menampakkan kemajuan. ${ }^{20}$

Kondisi ini terus berlangsung sejak masa tabi'in, seperti terbukti dari munculnya pendapat dari kalangan mereka tentang penggunaan hisab itu. Dalam Bidayatul Mujtahid misalnya, Ibnu Rusyd mengutip pendapat Mutharrif ibn al-Sukhair salah seorang tokoh tabi'in tentang kebolehan merujuk pada perhitungan hisab. Bahkan dikutip pula riwayat Ibn Suraij dari al-Imam as-Syafi'i yang membenarkan orang berpuasa berdasarkan ilmu hisab (al-istidlal bin nujumi wa manazilil qamar). ${ }^{21}$

Sejalan dengan semakin maju dan canggihnya ilmu hisab pada masa berikut terutama pada masa-masa terakhir ini, dapat dipahami apabila tuntutan untuk memberlakukan hasil perhitungan hisab dalam menentukan penetapan awal Ramadhan dan Syawal semakin kuat. Hal ini tidak saja muncul dalam bentuk menempatkan hisab sebagai pendamping rukyat, melainkan muncul dalam bentuk sikap menempatkan hisab sebagai yang

20 Muhyiddin Khazin, Mazhab Negara, Makalah.

${ }^{21}$ Ibn Rusyd, Bidayatul Mujtahid (Beirut: Darul Fikr, t.th), hal. 207. 
paling utama dari pada rukyat.

Memperhatikan perintah rukyat untuk mendeteksi kemunculan hilal, yang berarti manakala pada hari ke 29 hilal sudah muncul maka umur bulan 29 hari; dan apabila pada hari itu hilal tidak muncul maka umur bulan di sempurnakan (istikmal) berumur 30 hari. Dari ketentuan ini muncul pertanyaan "Mengapa istikmal hanya 30 hari?". Kemungkinan jawabnya antara lain bahwa pada saat matahari terbenam pada hari ke 30 itu secara hisab pasti sudah terjadi ijtima' serta posisi hilal pasti sudah di atas ufuk betapapun pada saat itu hilal tidak muncul karena terdapat awan atau semacamnya. Padahal ilmu hisab dapat memperhitungkan waktu ijtima' serta posisi hilal dengan akurat. Atas dasar itu, hisab berpeluang menjadi dasar penentuan awal bulan Qamariyah. ${ }^{22}$

Oleh sebab itu, dalam kaitannya dengan penentuan awal bulan Qamariyah di kalangan masyarakat terdapat dua kelompok besar, yakni kelompok yang berdasarkan pada rukyatul hilal dan kelompok yang berdasarkan pada hisab. Kedua kelompok ini masing-masing memiliki landasan yang dipandang kuat bahkan masing-masing merasa benar terhadap apa yang ditempuh oleh kelompoknya. Selain itu, masing-masing kelompok merasa memiliki otoritas hak dan kewajiban untuk memberikan bimbingan serta arahan pelaksanaan ibadah terhadap anggota kelompoknya masing-masing.

Kondisi inilah yang menjadi salah satu penghambat terciptanya penyatuan kalender Qamariyah di

22 Muhyiddin Khazin, Mazhab Negara, Makalah.
Indonesia, khusunya penentuan awal bulan Ramadhan, Syawal, dan Dzulhijjah yang merupakan hari besar dan hari syi'ar Islam.

\section{KONSEP MAZHAB NEGARA PENETAPAN AWAL BULAN}

Telah banyak usaha yang dilakukan untuk melakukan penyatuan kaledenr hijriyah atau qamariyah, namun sampai saat ini belum membuahkan hasil. Hal demikian ini dikarenakan permasalahan tentang rukyat dan hisab sebagai dasar penentuan awal bulan sangat kompleks, baik masalah bilangan orang yang bersaksi melihat hilal, siapa orangnya, kapan ia menyaksikannya, perlu dukungan hisab ataukah tidak, hisab mana yang dapat dijadikan dukungan, ada hisab urfi, taqribi dan tahkiki. Kriteria apa yang dijadikan pedoman pergantian bulan, ijtima' sebelum matahari terbenam, ijtima' sebelum tengah malam, ijtima' sebelum fajr, wujudul hilal, imkan rukyat, dan masalah matla'. Dengan kata lain, persoalan yang dihadapi tidak hanya pada person tetapi teori dan metode yang digunakan.

Untuk terciptanya kemaslahatan umat serta menjaga keutuhan dan persatuan bangsa Indonesia maka perlu dibangun mazhab berdiri sendiri yakni mazhab negara. Mazhab ini tentunya diusahakan dapat mengakomodir berbagai pendapat yang ada, selain tetap memperhatikan petunjuk Rasulullah Muhammad Saw dan perkembangan iptek (hisab). ${ }^{23}$ Dengan kata lain, mazhab negara adalah negara atau pemerintah yang mempunyai kekuatan dan kemampuan

${ }^{23}$ Ibid. $124 \begin{aligned} & \text { Mazhab Negara: Alternatif Solusi Terhadap Perbedaan Penentuan Awal Bulan } \\ & \text { Qamariyah Di Indonesia }\end{aligned}$ 
untuk menetapkan awal bulan yang dalam hal ini diwakili oleh Kementerian Agama.

Hal yang senada ditegaskan Mahyuddin Nawawi, bahwa andaikan saja negara atau mazhab negara memainkan perannya dengan maksimal, maka apa yang menjadi masalah khilafiyah dalam penentuan awal bulan akan dapat dicaikan solusinya yang selama ini terus berlanjut. ${ }^{24}$ Lanjutnya, mencontohkan bahwa Undang-Undang Perkawinan dan Kompilasi Hukum Islam (KHI) yang materinya tidak semua diterima oleh umat Islam Indonesia, misalnya, perlunya izin dari isteri dan hakim bagi suami yang beristri, harta gono gini dan sebagainya. Namun, hal itu akhirnya berjalan dan diterima karena telah menjadi keputusan negara sehingga mengikat semua umat Islam baik mereka yang setuju maupun yang tidak. ${ }^{25}$

Adapun yang perlu dilakukan oleh mazhab negara menurut Muhyiddin Khazin adalah sebagai berikut: 26

1. Mengingat bahwa sampai saat ini masih banyak sistem hisab yang berkembang di masyarakat, bahkan antara satu dengan lainnya terkadang menunjukkan perbedaan hasil perhitungan yang mencolok, maka kiranya mazhab negara ini perlu menetapkan sistem hisab yang dapat dijadikan sebagai acuan perhitungan tentang waktu ijtima'

24 Mahyuddin Nawawi, Menegakkan Mazhab Negara, dalam Choiruk Fuad Yusuf dan Bashori, Hisab Rukyat Dan Perbedaannya (Jakarta: Depag RI, 2004), hal. 229.

${ }^{25}$ Ibid., hal. 231.

${ }^{26}$ Ibid. maupun posisi hilal saat matahari terbenam, yakni hisab yang ketika menghitung ketinggian hilal menggunakan ilmu ukur segitiga bola dengan memperhatikan posisi bulan dan posisi tempat observasi, serta memberikan koreksi-koreksi yang diperlukan hingga hasil perhitungan menunjukkan tinggi hilal mar'i. ${ }^{27}$

2. Menetapkan dasar penentuan awal bulan Qamariyah. Sebagai dasar penentuan awal bulan Qamariyah harus memperhatikan petunjuk Rasulullah Muhammad Saw yaitu rukyatul hilal bil fi'li pada hari ke 29 bulan Qamariyah serta memperhatikan perkembangan iptek yakni hisab yang akurat, karena kedua cara tersebut merupakan alat bukti yang secara aplikatif masing-masing memiliki kelebihan serta kekurang-an. Sehingga kedua cara tersebut harus digunakan agar keduanya saling melengkapi atas kekurangan-kekurangan yang ada. ${ }^{28}$

3. Salah satu penyebab terjadinya perbedaan penentuan awal bulan qama-riyah adalah berbeda kriteria pergantian bulan. Sekalipun hasil hisabnya sama namun kalau kriteria yang digunakan berbeda maka akan berbeda pula hasil penentuannya. Oleh karena itu, mazhab negara ini dipandang perlu menentukan kriteria pergantian bulan Qamariyah sendiri.29

Adapun kriteria pergantian bulan
${ }^{27}$ Ibid.
${ }^{28}$ Ibid.
${ }^{29}$ Ibid. 
Qamariyah itu sangat diperlukan ketika menyusun kalender penanggalan dan diperlukan pula ketika menyikapi laporan hasil rukyat. Adapun Kriteria Pergantian Bulan (KPB) menurut mazhab negara adalah umur bulan minimal 8 jam dan nilai minimum antara ketinggian hilal (mar'i) dan beda azimut antara bulanmatahari ${ }^{30}$ sebagai berikut:

\begin{tabular}{|c|c|}
\hline TINGGI & AZIMUT \\
\hline \hline $08^{\circ} 20^{\prime}$ & $00^{\circ} 00^{\prime}$ \\
\hline $07^{\circ} 25^{\prime}$ & $00^{\circ} 30^{\prime}$ \\
\hline $06^{\circ} 35^{\prime}$ & $01^{\circ} 00^{\prime}$ \\
\hline $05^{\circ} 50^{\prime}$ & $01^{\circ} 30^{\prime}$ \\
\hline $05^{\circ} 10^{\prime}$ & $02^{\circ} 00^{\prime}$ \\
\hline $04^{\circ} 35^{\prime}$ & $02^{\circ} 30^{\prime}$ \\
\hline $04^{\circ} 00^{\prime}$ & $03^{\circ} 00^{\prime}$ \\
\hline $03^{\circ} 35^{\prime}$ & $03^{\circ} 30^{\prime}$ \\
\hline $03^{\circ} 10^{\prime}$ & $04^{\circ} 00^{\prime}$ \\
\hline $02^{\circ} 55^{\prime}$ & $04^{\circ} 30^{\prime}$ \\
\hline $02^{\circ} 35^{\prime}$ & $05^{\circ} 00^{\prime}$ \\
\hline $02^{\circ} 25^{\prime}$ & $05^{\circ} 30^{\prime}$ \\
\hline $02^{\circ} 15^{\prime}$ & $06^{\circ} 00^{\prime}$ \\
\hline
\end{tabular}

Melihat dari ketiga poin di atas maka selanjutnya yang dilakukan adalah:

${ }^{30}$ Ibid. a. Apabila menurut hisab yang akurat bahwa tinggi hilal di atas ufuk serta > KPB dan kenyataan hilal pun berhasil dirukyat, maka penentuan awal bulan berdasarkan rukyat yang didukung oleh hisab, sehingga umur bulan ybs 29 hari. Demikian ini sejalan dengan Hadis:

$$
\text { صوموا لرؤيته وأفطروا لرؤيته : } 31
$$

Artinya: Berpuasalah kalian karena terlihatnya hilal, dan berbukalah kalian karena terlihatnya hilal.

b. Apabila menurut hisab yang akurat bahwa hilal di bawah ufuk, serta kenyataan di lapangan hilal pun tidak berhasil dirukyat, maka penentuan awal bulan berdasarkan istikmal (umur bulan ybs 30 hari) yang didukung oleh hisab. Demikian ini sejalan dengan Hadis :

$$
\text { فإن غم عليكم فأكملوا العدة } 32
$$

Artinya: Jika penglihatanmu tertutup (oleh awan) maka sempurnakanlah bilangan itu.

c. Apabila menurut hisab yang akurat bahwa tinggi hilal di atas ufuk tetapi < KPB, namun terdapat laporan bahwa hilal berhasil dirukyat, maka kesaksian yang demikian itu dapat ditolak karena tidak didukung oleh ilmu pengetahuan, sehingga penentuan awal bulan berdasarkan istikmal (umur bulan 30 hari). Demikian ini seperti dikatakan oleh AlSyarwani:

31 Al-Bukhari, Shahih al-Bukhari, Juz I (Turki: Maktabah Islamiyah, 1979), hal 326.

${ }^{32}$ Ibid.

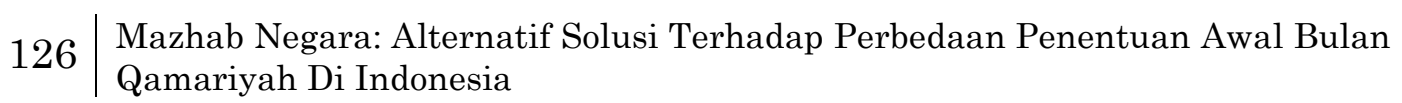


أن الحساب إن اتفق أهله على أن مقدماته قطعية

وكان المخبرون منهم بذلك عدد التواتر ردت

الشهادة وإلا فلا 33

Artinya: Bahwasanya hisab itu apabila para ahlinya (mencapai bilangan mutawatir) sepakat bahwa berdasarkan hitungannya yang akurat (hilal tidak dapat dirukyat) maka kesaksian rukyat itu ditolak. Kalau tidak demikian maka tidak.

Taqiyuddin as-Subki berkata:

$$
\begin{aligned}
& \text { إذا دل بمقدمات قطعية على عدم إمكان رؤية } \\
& \text { الهلال لم يقبل فيه الشهود } 34
\end{aligned}
$$

Artinya: Jika hisab menunjukkan secara pasti bahwa hilal tidak mungkin dapat dirukyat, maka kesaksian (telah melihat hilal) tidak dapat diterima.

Hal seperti ini dipahami pula dari Hadis Nabi:

$$
\begin{aligned}
& \text { جاء أعرابي إلى النبي صلعم فقال إنى رأيت } \\
& \text { الهلال قال أتشهد ان لا اله إلا الله قال نعم الكم } \\
& \text { قال أتشهد أن محمدا رسول الله قال نعم قال } \\
& \text { يا بلال أذن فن الناس فليصوموا غدا } 35
\end{aligned}
$$

Artinya: Seorang A'rabi (badui) telah datang kepada Nabi Saw, ia berkata "Sesungguhnya saya telah melihat hilal (Ramadhan)". Rasulullah bertanya: "Apakah engkau bersaksi bahwa tiada Tuhan selain Allah?". Ia menjawab: "Ya!". Rasulullah bertanya lagi: "Apakah engkau

33 Al-Syarwani, Khasyiyah Al-Syarwani'ala Tuhfatil Muhtaj, Juz III (Mesir: Maktabah Tijariyah Kubra, tth), hal. 382.

34 As-Subki, Al-Fatawa I (Mesir: Musthafa Babil Halabi, tth), hal. 219.

35 Al-Syaukani, Nailul Authar Juz IV (Mesir: Musthafa Babil Halabi, tth), hal. 209. bersaksi bahwa Muhammad utusan Allah?". Ia menjawab: "Ya!". kemudian Rasulullah bersabda: "Wahai Bilal, Serulah orang-orang supaya mereka berpuasa esok hari!.

Dari Hadis di atas dipahami bahwa ketika Rasulullah Saw menerima kesaksian rukyatul hilal dari A'rabi itu dikontrol oleh wahyu (Jibril), sehingga seandainya laporan A'rabi itu keliru, tentunya Jibril yang memberitahukannya. Namun untuk masa sekarang ini, ilmu (hisab) pengganti fungsi Jibril. Oleh karena itu, laporan rukyat dapat ditolak manakala materi laporan itu tidak didukung oleh ilmu pengetahuan (hisab).

d. Apabila menurut hisab yang akurat bahwa tinggi hilal di atas ufuk serta > KPB, namun kenyataan hilal tidak berhasil dirukyat di Indonesia karena terdapat awan atau semacamnya, sementara negara lain yang posisinya semathla' dengan Indonesia atau di sebelah timurnya serta memiliki tinggi hilal di atas ufuk > KPB dan berhasil melihat hilal maka penentuan awal bulan berdasarkan hasil rukyat negara lain itu. Dengan demikian keumuman perintah "shumu li ru'yatihi ..." dapat dijalankan.

An-Nawawi berkata:

$$
\text { فإِان تقارب أوا الهلال في رمضان في بلد ولم يروه في غيره }
$$

Mazhab Negara: Alternatif Solusi Terhadap Perbedaan Penentuan Awal Bulan Qamariyah Di Indonesia 


$$
\text { ويلزم أهل البلد الآخر الصوم بلا خلاف } 36
$$

Artinya: Apabila hilal Ramadhan itu terlihat di suatu negara, sementara di negara lain tidak terlihat, apabila kedua negara itu dekat maka hukum kedua negara itu sama, sehingga bagi negara lain pun wajib berpuasa. Yang demikian itu tidak diperselisihkan.

e. Apabila menurut hisab yang akurat bahwa tinggi hilal di atas ufuk > KPB atau pada ketinggian tertentu yang umumnya hilal dapat dirukyat, namun kenyataan hilal tidak berhasil dirukyat di Indonesia karena terdapat awan atau semacamnya, sementara negara lain yang posisinya semathla' dengan Indonesia atau di sebelah timurnya serta memiliki tinggi hilal di atas ufuk > KPB namun juga tidak berhasil melihat hilal, maka penentuan awal bulan berdasarkan hisab, bahwa malam itu dan keesokan harinya merupakan tanggal satu bulan berikutnya. Dengan demikian umur bulan 29 hari.

Al-Qusyairi berkata:

$$
\begin{aligned}
& \text { إذا دل الحساب على أن الهلال قد طلع من الأفق } \\
& \text { على وجه يرى لولا وجود المانع كالغيم مثلا فهذا } \\
& \text { يقتضالوجوب لوجود السبب الشرعي } 37 \\
& \text { Artinya: Apabila hisab }
\end{aligned}
$$

36 An-Nawawi, Al-Majmu' Juz VI (Mesir: Musthafa Babil Halabi, t.th), hal. 273.

37 Ibn Rusyd, Bidayatul Mujtahid, Juz I, hal. 242. wajibnya berpuasa karena adanya sebab syar'iy.

Al-Ramli Al-Syarwani seperti yang dinukil oleh Zubair berkata bahwa apabila hisab qath iy menunjukkan adanya hilal dan mungkin dapat dirukyat, tetapi setelah dilakukan rukyah bil fi li ternyata tidak ditemukan hilal karena adanya mani (penghalang), maka cukuplah dengan berdasarkan imkan rukyat itu untuk menentukan pergantian bulan. ${ }^{38}$

4. Menjadikan Keputusan Menteri Agama tentang penentuan awal bulan Qamariyah sebagai suatu peraturan yang mengikat bagi seluruh rakyat Indonesia. Oleh karena itu, fatwa MUI nomor 2 tahun 2004 tentang penetapan awal Ramadhan, Syawal dan Dzulhijjah $^{39}$ perlu lebih disosialisasikan agar masyarakat umum mengetahui dan timbul kesadaran untuk mengikuti Keputusan Menteri Agama.40 Al-Qalyubi berkata:

$$
\text { عند القاضد فن الوجوب على من لم يره من ثبوت رؤيته }
$$

Artinya: Suatu kewajiban bagi orang yang tidak melihat hilal

38 Zubair Umar al-Jailani, al-Khulashatul Wafiyah (Kudus: Menara, tth), h 134. lihat juga Al-Syirazi, Al-Muhadzdzab, Juz I, h.180, Ibn Rusyd, Bidayatul Mujtahid, Juz I, hal. 207.

39 Fatwa MUI Nomor 2 tahun 2004 tentang Penetapan Awal Ramadlan, Syawal, dan Dzulhijjah tertanggal 05 Dzulhijjah 1424 H (24 Januari 2004)

40 Muhyiddin Khazin, Mazhab Negara, Makalah.

41 Al-Qalyubi, Minhajut Thalibin (Mesir: Musthafa Babil Halabi, tth), Juz II, hal. 49.

$128 \begin{aligned} & \text { Mazhab Negara: Alternatif Solusi Terhadap Perbedaan Penentuan Awal Bulan } \\ & \text { Qamariyah Di Indonesia }\end{aligned}$ 
(sendiri) adalah ketetapan adanya hilal menurut keputusan qadli (pemerintah).

Al-Syarwani berkata:

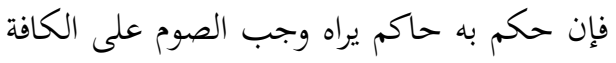

Artinya: Apabila hakim telah menetapkan terlihatnya hilal maka puasa wajib dilaksanakan bagi seluruh penduduk di negeri itu.

5. Fatwa MUI Nomor 2 tahun 2004 itu mesti ditingkatkan statusnya dari fatwa yang sifatnya tidak mengikat menjadi Undang-undang sehingga memiliki kekuatan hukum. ${ }^{43}$

Pada prinsipnya penetapan awal bulan qamariyah merupakan kajian fikih yang sifatnya zhonni atau bersifat ijtihadi infiradi. Artinya bahwa penetapan awal bulan adalah masalah ijtihad yang sifatnya individual. Oleh sebab itu, bagi yang melakukan rukyat maka bagi dirinya kewajiban untuk melaksanakan hasil rukyat dan orang yang mempercayainya. Senada dengan itu, mereka yang melakukan hisab maka kewajibannya bagi orang yang melakukan hisab dan yang mempercayainya. Sementara itu, Orang awam diberikan pilihan untuk memilih pendapat mana yang diinginkan untuk diikutinya.

Melihat fakta kebebasan dalam memilih pendapat dalam konteks penetapan awal bulan di Indonesia telah terjadi perbedaan penentuan awal Syawal yang dengan perbedaan

42 Al-Syarwani, Khasyiyah Al-Syarwani ‘ala Tuhfatil Muhtaj, Juz I, hal. 376.

43 Muhyiddin Khazin, Mazhab Negara, Makalah. itu membawa dampak kepada persoalan yang lebih kompleks terkait dengan kesatuan dan persatuan umat terlebih lagi bangsa. Oleh sebab itu, persoalan penetapan awal bulan Qamariyah, khususnya Ramadhan, Syawal, dan Dzulhijjah tidak lagi dianggap dan dipandang sebagai fikih ijtihadi infiradi yang sifatnya individual namun meningkat menjadi fikih ijtihadi yang bercorak kemasyarakatan. ${ }^{44}$

Dalam khazanah fikih bahwa persoalan yang bersifat kemasyarakatan campurtangan dan keikutsertaaan ulil amr atau pemerintah dalam masalah tersebut dibenarkan untuk mencapai kemaslahatan umum. Oleh sebab itu, persoalan penentuan awal bulan Ramadhan, Syawal, dan Dzulhijjah (di Indonesia) dipandang perlu adanya campurtangan ulil amr (pemerintah), bahkan dipandang perlu pula adanya pendapat bahwa Pemerintah yang berhak menentukan awal-awal bulan Qamariyah itu, sehingga kaidah "Hukmul hakim ilzamun wa yarfa'ul khilaf' (Keputusan hakim itu mengikat (wajib dipatuhi) dan menghilangkan silang pendapat $)^{45}$ dapat terealisir.

Dalam fikih Syafi'i menjelaskan bahwa penentuan awal dan akhir bulan Ramadhan harus ditetapkan oleh ulil amr atau pemerintah. Apabila pemerintah telah menentukannya maka seluruh masyarakat harus mematuhinya.46 Sementara jumhur

\footnotetext{
${ }^{44}$ Ibid.

45 Al-Syarwani, Khasyiyah Al-Syarwani'ala Tuhfatul Muhtaj, Juz III, hal. 383.

46 Al-Jazari, Al-Fiqh 'ala Madzahibil Arba'ah, Juz I (Mesir: At-Tijariyah Kubra, tth), hal. 433.
} 
ulama (Hanafiyah, Malikiyah, dan Hanabilah) tidak mengharuskan adanya penentuan oleh pemerintah. Tetapi apabila pemerintah menentukannya maka ketentuan pemerintah ini mengikat bagi seluruh masyarakat. ${ }^{47}$

Dengan demikian, dapat diketahui bahwa apabila ulil amr (pemerintah) telah menentukan awalawal bulan tersebut maka seluruh umat Islam yang berada di wilayah pemerintahan itu harus tunduk dan mengikuti apa yang telah ditentukan. Hal ini tentuntunya dalam konteks di Indonesia bahwa jika pemerintah telah menentukan dan menetapkan bulan baru Qamariyah, bulan Ramadhan, bulan Syawal, maupun Zulhijjah seyogianya seluruh umat Islam di Indonesia mengikuti keputusan pemerintah tersebut.

Dalam konteks ini, pada prinsipnya peran negara menjadi strategis untuk menyelesaikan persoalan yang berkepanjangan. Upaya melahirkan undang-undang yang mengatur persoalan keberagamaan yang di dalamnya termaktub persoalan penentuan awal bulan Qamariyah yang sifanya solusi akan memberikan dampak yang lebih menggembirakan.

Dapat dijelaskan misalnya, UndangUndang No 1. Tahun 1974 tentang perkawinan mengandung masteri-materi hukum yang tidak disepakati fikih Islam, harta gono gini, suami untuk menikah lagi harus ada izin dari isteri dan hakim dan sebagainya, tetapi setelah diundangkan ternyata dipakai dan dipatuhi masyarakat. Hal ini tentunya menjadi cerminan bahwa ssetelah diundangkan kemungkinan persoalan penentuan awal bulan akan selesai.

Namun, satu hal yang mungkin perlu disadari secara bersama oleh ormas-ormas Islam yang memiliki metode tersendiri dalam penentuan awal bulan perlu untuk membuka diri terhadap gagasan untuk penyatuan tanggal penentuan awal bulan yang ditetapkan negara. Tentunya hal ini adalah persoalan kemampuan untuk mengedepankan kemaslahatan umat Islam secara kolektif bukan kepentingan kelompok dan golongan.

\section{PENUTUP}

Mazhab negara merupakan terobosan baru yang mesti direalisasikan dalam penentuan awal bulan Qamariyah dalam rangka menjembatani pandangan umat Islam yang berbeda tentang penetapa awal bulan. Selain itu, melalui mazhab negera dapat menyatukan umat Islam bulan sehingga dalam melaksanakan ibadah dengan bersamaan tanpa perbedaan. Kendati demikian, tentunya masih perlu dilakukan upaya yang serius untuk merealisasikannya dengan segala problema dan dinamikanya.

\footnotetext{
47 Ibid., hal. 434.
}

130 |l $\begin{aligned} & \text { Mazhab Negara: Alternatif Solusi Terhadap Perbedaan Penentuan Awal Bulan } \\ & \text { Qamariyah Di Indonesia }\end{aligned}$ 


\section{DAFTAR PUSTAKA}

Al-Bukhari, Shahih al-Bukhari, Juz I (Turki: Maktabah Islamiyah, 1979).

Al-Jazari, Al-Fiqh 'ala Madzahibil Arba'ah, Juz I (Mesir: At-Tijariyah Kubra, tth).

Al-Qalyubi, Minhajut Thalibin (Mesir: Musthafa Babil Halabi, tth), Juz II.

Al-Syarwani, Khasyiyah Al-Syarwani'ala Tuhfatil Muhtaj, Juz I.

Al-Syarwani, Khasyiyah Al-Syarwani‘ala Tuhfatil Muhtaj, Juz III (Mesir: Maktabah Tijariyah Kubra, tth).

Al-Syarwani, Khasyiyah Al-Syarwani'ala Tuhfatul Muhtaj, Juz III.

Al-Syaukani, Nailul Authar Juz IV (Mesir: Musthafa Babil Halabi, tth).

Al-Syirazi, Al-Muhadzdzab, Juz I, h.180, Ibn Rusyd, Bidayatul Mujtahid, Juz I.

An-Nasa'i, Sunan an-Nasa'I, Juz I (Mesir: Musthafa Babil Halabi, 1979).

An-Nawawi, Al-Majmu’Juz VI (Mesir: Musthafa Babil Halabi, t.th).

As-Subki, Al-Fatawa I (Mesir: Musthafa Babil Halabi, tth).

Bukhari, Shahih Bukhari, Juz III (Beirut: Dar al-Kutub al-Ilmiyah, t.th.).

Departemen Agama, Alquran Dan Terjemahnya (Semarang: Toha Putra, 1989).

Fatwa MUI Nomor 2 tahun 2004 tentang Penetapan Awal Ramadlan, Syawal, dan Dzulhijjah tertanggal 05 Dzulhijjah 1424 H (24 Januari 2004)

Ibn Rusyd, Bidayatul Mujtahid (Beirut: Darul Fikr, t.th).

Ibn Rusyd, Bidayatul Mujtahid, Juz I,

Mahyuddin Nawawi, Menegakkan Mazhab Negara, dalam Choiruk Fuad

Muslim, Shahih Muslim, Juz I (Bairut: Darul Fikr, tth).

Yusuf al-Qaradlawi, Fiqh ash-Shiyam (Kairo: Dar Ash-Shahwah, 1991).

Yusuf dan Bashori, Hisab Rukyat Dan Perbedaannya (Jakarta: Depag RI, 2004).

Zubair Umar al-Jailani, al-Khulashatul Wafiyah (Kudus: Menara, tth). 